\title{
Leukotriene modifiers for asthma treatment
}

\author{
P. Montuschi ${ }^{1}$ and M. L. Peters-Golden ${ }^{2}$ \\ ${ }^{1}$ Department of Pharmacology, Faculty of Medicine, Catholic University of the Sacred Heart, Rome, Italy and ${ }^{2}$ Department of Internal Medicine, Division of Pulmonary \\ and Critical Care Medicine, University of Michigan Medical School, Ann Arbor, MI, USA
}

\section{Clinical \&t Experimental Allergy}

Correspondence:

Paolo Montuschi, Department of

Pharmacology, Faculty of Medicine, Catholic University of the Sacred Heart, Largo Francesco Vito, 1 - 00168 Rome, Italy.

E-mail: pmontuschi@rm.unicatt.it Cite this as: P. Montuschi and M. L. Peters-Golden, Clinical \&t Experimental Allergy, 2010 (40) 1732-1741.

\section{Summary}

Leukotrienes (LTs), including cysteinyl LTs (CysLTs) and $\mathrm{LTB}_{4}$, are potent lipid mediators that have a role in the pathophysiology of asthma. At least two receptor subtypes for CysLTs, CysLT $_{1}$ and $\mathrm{CysLT}_{2}$, have been identified. The activation of the CysLT $\mathrm{C}_{1}$ receptor is responsible for most of the pathophysiological effects of CysLTs in asthma, including increased airway smooth muscle activity, microvascular permeability, and airway mucus secretion. LTB $_{4}$ might have a role in severe asthma, asthma exacerbations, and the development of airway hyperresponsiveness. CysLT ${ }_{1}$ receptor antagonists can be given orally as monotherapy in patients with mild persistent asthma, but these drugs are generally less effective than inhaled glucocorticoids. Combination of $\mathrm{CysLT}_{1}$ receptor antagonists and inhaled glucocorticoids in patients with more severe asthma may improve asthma control and enable the dose of inhaled glucocorticoids to be reduced while maintaining similar efficacy. The identification of subgroups of asthmatic patients who respond to $\mathrm{CysLT}_{1}$ receptor antagonists is relevant for asthma management as the response to these drugs is variable. CysLT $_{1}$ receptor antagonists have a potential anti-remodelling effect that might be important for preventing or reversing airway structural changes in patients with asthma. This review discusses the role of LTs in asthma and the role of LT modifiers in asthma treatment.

\section{Introduction}

Leukotrienes (LTs), including cysteinyl LTs (CysLTs) ( $\mathrm{LTC}_{4}$, $\mathrm{LTD}_{4}$, and $\mathrm{LTE}_{4}$ ) and $\mathrm{LTB}_{4}$, are potent lipid mediators that derive from arachidonic acid through the 5-lipoxygenase (5L0) pathway [1-5]. The pathway for the complete synthesis of CysLTs is highly expressed in several types of inflammatory cells and becomes activated during allergic airway inflammation [3,5]; other cell types like platelets and endothelial cells, while lacking the complete synthetic pathway, can produce CysLTs from the chemically reactive intermediate $\mathrm{LTA}_{4}$ via mechanisms of intercellular transfer [5].

LTs have a central role in asthma [1-4, 6], but their importance may vary among asthmatic patients. CysLTs induce a variety of pathophysiological responses that contribute to asthma, while the role of $\mathrm{LTB}_{4}$ in disease expression may be more restricted.

This review will examine the role of LTs in asthma and the therapeutic implications of LT pathway inhibition for asthma.

\section{Biosynthesis and metabolism of leukotrienes}

LTs derive from the enzymatic activity of 5-LO (Fig. 1). Arachidonic acid, esterified in plasma membrane phos- pholipids, is cleaved by the action of various phospholipase $A_{2}$ isoenzymes and the released fatty acid is transformed by 5-LO into $\mathrm{LTA}_{4}$. This LT is subsequently metabolized by $\mathrm{LTA}_{4}$ hydrolase into $\mathrm{LTB}_{4}$ and by $\mathrm{LTC}_{4}$ synthase or other members of the membrane-associated proteins in eicosanoid and glutathione metabolism (MAPEG) superfamily, including microsomal glutathione transferase 2, into $\mathrm{LTC}_{4}$ [5]. This, in turn, is metabolized by a $\gamma$-glutamyl transpeptidase into $\mathrm{LTD}_{4}$, which is then cleaved by a dipeptidase to $\mathrm{LTE}_{4}$. The highly reactive $\mathrm{LTA}_{4}$ has an estimated half-life of $<3 \mathrm{~s}$ [5]. LTC ${ }_{4}, \mathrm{LTD}_{4}$ and LTE are known as CysLTs due to the common cysteine in the side chain. Initiation of LT biosynthesis requires cellular activation of phospholipase $\mathrm{A}_{2}$ and 5-LO by stimuli including IgE receptor cross-linking on mast cells, and also involves the five-lipoxygenase-activating protein (FLAP) that binds and facilitates the transfer of arachidonic acid to 5-LO [2, 3, 5]. The intracellular compartmentalization of 5-LO varies between different cell types. 5-LO is mainly expressed in granulocytes, monocytes, macrophages, and mast cells [3]. Eosinophils and mast cells can produce large amounts of $\mathrm{LTC}_{4}$ from an endogenous pool of arachidonic acid. Human bronchial fibroblasts, that constitutively express 5-LO, FLAP, LTA $_{4}$ hydrolase, and 
LTC 4 synthase, produce CysLTs and $\mathrm{LTB}_{4}$ in vitro [7]. However, fibroblasts and other structural cells have a lower capacity for LT synthesis than do leucocytes [1]. Cells that do not express 5-LO, including platelets, erythrocytes, and endothelial cells can also produce CysLTs and/or $\mathrm{LTB}_{4}$ through the transcellular metabolism of $\mathrm{LTA}_{4}$ synthesized by activated neutrophils [5]. After their intracellular formation, CysLTs and $\mathrm{LTB}_{4}$ are released to the extracellular space through specific carrier proteins that are potential targets for new anti-LT drugs [3].

\section{Receptors, mechanism of action, and biological effects of leukotrienes in the airways}

Two G-protein coupled receptor subtypes for CysLTs $\left(\right.$ CysLT $_{1}$ and CysLT $_{2}$ ) have been identified [8, 9] (Fig. 1). Evidence supporting the existence of other CysLT receptors is growing rapidly [10-14]. In mice lacking CysLT $_{1}$ and $\mathrm{CysLT}_{2}$ receptors, $\mathrm{LTE}_{4}$ increases vascular permeability, suggesting the existence of a third CysLT receptor that responds preferentially to $\mathrm{LTE}_{4}$ [10]. In sensitized mice, intranasal $\mathrm{LTE}_{4}$ potentiates pulmonary inflammation in response to low-dose aerosolized antigen [12]. This effect persists in mice lacking both $\mathrm{CysLT}_{1}$ and $\mathrm{CysLT}_{2}$ receptors but not in mice lacking $\mathrm{P}_{2} \mathrm{Y}_{12}$ receptors, indicating that the $\mathrm{P}_{2} \mathrm{Y}_{12}$ receptor is required for pro-inflammatory effects of $\mathrm{LTE}_{4}$ [12]. Although $\mathrm{LTE}_{4}$ has little activity at $\mathrm{CysLT}_{1}$ and $\mathrm{CysLT}_{2}$ receptors [13], inhalation of $\mathrm{LTE}_{4}$ increases airway inflammatory cells $[15,16]$ and airway hyperresponsiveness (AHR) in asthmatic patients [17], particularly in those with aspirin-sensitive asthma (ASA) [13]. A G-protein-coupled receptor (GPCR) GPCR17, that responds both to CysLTs and uracil nucleotides [14], is a ligand-independent, constitutive negative regulator for the CysLT $_{1}$ receptor at the cell membrane [11]. GPR17 negatively regulates $\mathrm{CysLT}_{1}$ receptor-mediated inflammation in the lung following intranasal sensitization and challenge with the house dust mite in mice [18]. Many of the effects of CysLTs that are relevant to the pathophysiology of asthma are mediated by the activation of the CysLT $_{1}$ receptor $[1,2]$, which is expressed in mast cells, monocytes, and macrophages, eosinophils, basophils, neutrophils, T and B lymphocytes, pluripotent haemopoietic stem cells $\left(\mathrm{CD} 34^{+}\right)$, airway smooth muscle cells, bronchial fibroblasts, and vascular endothelial cells [7, 8, 19]. The $\mathrm{CysLT}_{2}$ receptor is expressed in human peripheral basophils [20], endothelial cells [21], cultured mast cells [9], in peripheral blood eosinophil from patients with asthma [22], and in nasal mast cells and eosinophils in patients with active seasonal allergic rhinitis (AR) [23]. In human cultured mast cells, CysLT 2 activation induces IL-8 synthesis that may promote neutrophilic inflammation [9], a characteristic of acute and severe asthma. The role of the $\mathrm{CysLT}_{2}$ receptor in acute asthma, and more generally in allergic airway inflammation is currently largely unknown. The development of selective $\mathrm{CysLT}_{2}$ antagonists [24] should facilitate its elucidation. CysLT $_{1}$ and $\mathrm{CysLT}_{2}$ receptor activation triggers increased intracellular calcium $[8,25]$, but the complete signal transduction pathway from each receptor is incompletely understood.

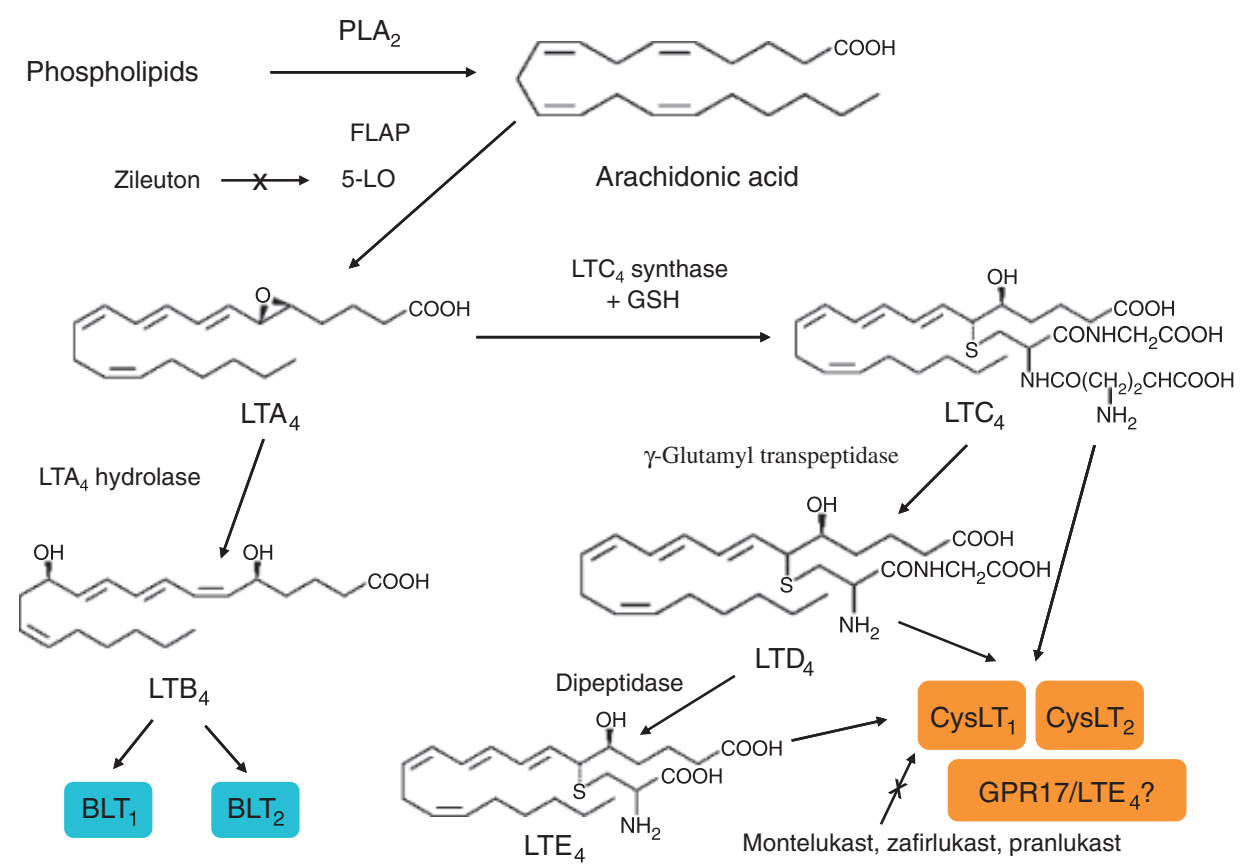

Fig. 1. Biosynthetic pathway of leukotrienes (LTs), LT receptors, and mechanisms of action of anti-LT drugs (modified with permission from Montuschi et al. [2]). CysLT, cysteinyl leukotrienes; FLAP, five-lipoxygenase-activating protein; GSH, glutathione; 5-LO = 5-lipoxygenase; $\mathrm{PLA}_{2}$, phospholipase $\mathrm{A}_{2}$. 
Two $\mathrm{LTB}_{4}$ receptor subtypes $\left(\mathrm{BLT}_{1}\right.$ and $\mathrm{BLT}_{2}$ ), that like CysLT $_{1}$ and CysLT $_{2}$ are cell-surface $\mathrm{G}$ protein-coupled seven transmembrane domain receptors, have been identified $[26,27]$. Both receptor subtypes are expressed in a human mast cell line (HMC-1) [28]. BLT $_{1}$ receptors are expressed in human bronchial fibroblasts [7], neutrophils, and monocytes/macrophages [29]. A subset of $\mathrm{CD}^{+} \mathrm{T}$ cells expressing BLT $_{1}$ receptors have been identified in BAL and lung tissue from patients with asthma, but not from healthy subjects [30]. BLT ${ }_{1}$ expression on $\mathrm{Ag}$-primed $\mathrm{T}$ cells [30] and dendritic cells [31] is required for the development of AHR in mice. The absence of $\mathrm{BLT}_{1}$ receptors or their antagonism on these cells markedly reduces allergen challenge-induced AHR and airway inflammation in mice [30-32]. Taken together, these data suggest a possible role for $\mathrm{LTB}_{4}$ in AHR and allergic airway inflammation in asthmatic patients. Glucocorticoids upregulate BLT $_{1}$ expression on corticosteroid-resistant inflammatory cells including neutrophils, monocytes, and effector memory $\mathrm{CD}^{+}{ }^{+} \mathrm{T}$ cells $[29,33]$. The number of $\mathrm{CD}^{+}{ }^{+} \mathrm{T}$ cells is increased in patients with steroid-resistant asthma compared with those with steroid-sensitive asthma [30]. This corticosteroid-resistant $\mathrm{LTB}_{4} / \mathrm{BLT}_{1}$ pathway may contribute to the development of inflammation in allergic diseases that do not respond to glucocorticoids [29], including steroid-resistant asthma for which the inhibition of this pathway might have a therapeutic benefit. However, the biological significance of $\mathrm{LTB}_{4}$-induced activation of effector $\mathrm{CD}^{+}{ }^{+} \mathrm{T}$ cells in asthmatic patients is yet to be established. The lack of effect of $\mathrm{LTB}_{4}$ receptor antagonists in allergen-induced early or latephase airway obstruction in asthmatic patients [34] argues against an important role for $\mathrm{LTB}_{4}$ in acute bronchoconstriction. A possible contribution of $\mathrm{BLT}_{2}$ to airway inflammation and asthma is beginning to be appreciated [35]. $\mathrm{LTB}_{4}$ is a physiologically relevant peroxisome proliferator-activated receptor (PPAR) activator in cells of the immune system [36]. PPAR- $\alpha$ activation, a direct effect of intracellularly generated $\mathrm{LTB}_{4}$ binding to the nuclear receptor and not of secreted $\mathrm{LTB}_{4}$ acting through its cell-surface receptors [36], reduces levels of $\mathrm{LTB}_{4}$ by stimulating its degradation, thereby limiting the pro-inflammatory effects of $\mathrm{LTB}_{4}$ [36].

CysLTs induce pathophysiological responses similar to those that are observed in patients with asthma [1-3]. $\mathrm{LTC}_{4}$, $\mathrm{LTD}_{4}$, and $\mathrm{LTE}_{4}$, the most potent endogenous bronchoconstrictors, have similar contractile activity on human airway smooth muscle in vitro, an effect that has been confirmed by bronchoprovocation studies in healthy subjects [3]. Patients with asthma are hyperresponsive to inhalation of $\mathrm{LTC}_{4}$, $\mathrm{LTD}_{4}$, and $\mathrm{LTE}_{4}$ [3]. CysLTs are elevated in adults and children with exercise-induced bronchoconstriction (EIB) $[37,38]$. CysLTs increase pulmonary microvascular permeability in experimental animals and increase mucus secretion in isolated animal and human airways [3]. These effects can contribute to bronchial obstruction in patients with asthma. CysLT inhalation in asthmatic patients increases sputum eosinophil counts and induces the recruitment of eosinophils into airway mucosa [39]. However, the role of direct vs. indirect mechanisms in the eosinophil chemotactic effect of CysLTs remains to be completely defined.

In addition to their local airway effects, CysLTs exert several effects that contribute to the inflammatory process that characterizes asthma [4, 40]. CysLTs (1) modulate leukopoiesis induced by granulocyte-macrophage colony-stimulating factor, IL-5, and IL-3 and prime progenitor cells to differentiate into mature blood cells; (2) cause leucocyte migration from the bone marrow into the circulatory system; (3) induce chemotaxis of eosinophils, increasing their cellular adhesion and transendothelial migration into the airways; (4) increase eosinophil survival in response to mast cell and lymphocyte paracrine signals; and (5) activate mast cells, eosinophils, T lymphocytes, monocytes, and basophils $[4,40]$. CysLTs have a central role in pulmonary inflammation induced by allergen challenge, as reflected by the reduced $\mathrm{Th}_{2}$ cell-dependent inflammatory response in $\mathrm{LTC}_{4}$ synthase null mice [41].

CysLTs might participate in the process of airway remodelling that includes eosinophilic inflammation, airway smooth muscle cell hyperplasia, mucus gland hyperplasia, mucus hypersecretion, and collagen deposition beneath the epithelial layer and in the lung interstitium at sites of leucocyte infiltration [42].

$\mathrm{LTB}_{4}$ may contribute to airway narrowing by producing local oedema and increasing mucus secretion, although $\mathrm{LTB}_{4}$ has no bronchoconstrictor effect in healthy subjects and patients with asthma [2, 3]. $\mathrm{LTB}_{4}$ might be functionally involved in the neutrophilic phenotype of asthma that characterizes patients with severe asthma [43] or asthma exacerbations due to its potent chemoattractant activity for neutrophils. $\mathrm{LTA}_{4}$ hydrolase inhibition attenuates allergic airway inflammation and AHR in a mast cell-dependent murine model of allergic airway inflammation [44]. Persistently elevated plasma $\mathrm{LTB}_{4}$ concentrations in children 1 month after an asthma exacerbation [45], and elevated $\mathrm{LTB}_{4}$ concentrations in EBC in adults with mild asthma [46] and children with mild-to-moderate persistent asthma [47], could indicate a pathophysiological role of $\mathrm{LTB}_{4}$ in persistent asthma of lesser severity [48]. However, the pathophysiological role of $\mathrm{LTB}_{4}$ in asthma is not completely defined and requires further studies. Selective $\mathrm{CysLT}_{1}$ receptor antagonists have only a modest inhibitory effect on AHR $[4,49]$. By contrast, a possible role for $\mathrm{LTB}_{4}$ in AHR is suggested by the fact that chronic treatment with zileuton, which reduces the synthesis of both CysLTs and $\mathrm{LTB}_{4}$, decreases AHR in asthmatic patients $[50,51]$ concomitant with a reduction of ex vivo $\mathrm{LTB}_{4}$ production [51]. Unlike $\mathrm{CysLT}_{1}$ receptor antagonism [52], 5-LO inhibition is very effective in promoting chronic improvement in nasal function in patients with ASA at baseline [50]. These data suggest that $\mathrm{LTB}_{4}$ may have a pathophysiological role in the nasal manifestations of ASA. Alternatively, or 
additionally, nasal symptoms in patients with ASA could be due to activation of CysLT 2 receptors or distinct $\mathrm{LTE}_{4}$ receptors [10-14], which are not blocked by CysLT $_{1}$ receptor antagonists.

\section{Measurement of leukotrienes in biological fluids in patients with asthma}

LTs have been measured in EBC [46, 47, 53-61], sputum [55, 62, 63], BAL fluid [64], and urine [65-67] in patients with asthma. Several studies reported increased LT concentrations in EBC in both adults and children with asthma [46, 47, 53-61], but this methodology requires standardization [56, 68, 69]. Sputum CysLT concentrations are elevated in asthmatic patients, reflecting asthma severity [63]. LT concentrations are increased in BAL fluid in patients with asthma, including those with nocturnal asthma [64]. Measurement of LTs in BAL fluid, sputum, and EBC is likely to reflect pulmonary synthesis of these mediators.

Urinary measurement of $\mathrm{LTE}_{4}$, the stable end-metabolite of CysLTs and therefore the most abundant CysLT excreted in the urine, is used for assessing the systemic synthesis of CysLTs, because circulating concentrations of LTs are usually undetectable [65]. No or slight differences have generally been reported in urinary $\mathrm{LTE}_{4}$ concentrations between healthy and atopic asthmatic subjects under basal conditions [65]. By contrast, urinary $\mathrm{LTE}_{4}$ excretion is elevated after allergen challenge in atopic patients with asthma [3, 65], in aspirin-sensitive asthmatics under basal conditions $[66,70]$, in patients with nocturnal asthma [64], in severe asthma [71], and during asthma exacerbations [67].

\section{The effects of leukotriene modifiers in asthma}

Selective CysLT $_{1}$ receptor antagonists that have been approved for clinical use in asthma include montelukast, zafirlukast, and pranlukast. Zileuton, a 5-LO inhibitor, has been approved for the prevention and chronic treatment of asthma in adults and children 12 years of age and older in the United Kingdom and United States. FLAP inhibitors such as MK-886 [72], MK-0591 [73], and veliflapon (BAY-X1005, DG-031) [74] were shown to be effective in clinical trials with patients with asthma in the mid-1990s, but, unlike CysLT $_{1}$ receptor antagonists, these compounds were not marketed [75]. Novel FLAP inhibitors including 2190914 (AM-103) [76, 77] and GSK-2190915 have entered phase II trials for the treatment of asthma [75].

Montelukast is the most prescribed CysLT $_{1}$ receptor antagonist in Europe and North America, whereas pranlukast is only marketed in Japan and other Asian countries. Zafirlukast was the first anti-LT that was approved in Europe, but it is not frequently prescribed due to possible food and drug interactions, and the twice-daily administration regimen $[2,3]$. Selective $\mathrm{CysLT}_{1}$ receptor antagonists and 5-LO inhibitors appear to have similar efficacy in short-term treatment studies and challenge models, suggesting that most of the anti-asthmatic effects of anti-LTs are due to CysLT 1 antagonism [3]. However, the strength of this assumption is limited by the lack of direct comparisons of the two classes of agents in large patient populations. The use of zileuton has been limited by a modest but distinct incidence of hepatic enzyme elevation that is not observed with montelukast, and its short halflife, which initially demanded four times daily administration [3]. A twice-daily controlled-release formulation of zileuton was subsequently approved by the Food and Drug Administration (FDA) [1].

At least two properties of selective 5-LO inhibitors that distinguish them from CysLT $_{1}$ receptor antagonists deserve emphasis and further investigation: (1) their greater effects on AHR in asthmatic patients than those of CysLT 1 receptor antagonists [4]; and (2) their greater efficacy in reducing nasal symptoms in patients with ASA [50].

CysLT $_{1}$ receptor antagonists improve symptoms and lung function, and reduce exacerbation rate, the use of $\beta_{2}$ bronchodilators, and airway and blood eosinophilia in adults and children with asthma of varying severity [1-4]. In patients with persistent asthma who are undertreated and remain symptomatic while taking short-acting $\beta_{2}$-agonists alone, CysLT 1 receptor antagonists provide a prompt improvement in asthma control, although low-dose inhaled glucocorticoids are generally more effective than CysLT $_{1}$ receptor antagonists as first-line maintenance therapy [78].

As add-on therapy, LTRAs are effective for acute asthma $[79,80]$. When added to standard therapy in adults with asthma exacerbations, intravenous montelukast $(7 \mathrm{mg})$ significantly improves airway obstruction throughout the $2 \mathrm{~h}$ after administration, with the onset of action as early as $10 \mathrm{~min}$, indicating a possible therapeutic role for $\mathrm{CysLT}_{1}$ receptor antagonists in severe acute asthma [79, 80]. However, the utility of oral montelukast in this setting has not been studied and intravenous formulation is not being clinically developed at present.

CysLT $_{1}$ receptor antagonists are effective in reducing early and late asthmatic responses induced by allergen inhalation [81, 82]. Unlike budesonide, montelukast inhibits the maximal early asthmatic response, whereas both drugs attenuate the late asthmatic response [81]. However, anti-LTs reduce allergen-induced AHR to a lesser extent than do inhaled glucocorticoids [81]. This could be explained by the fact that AHR is multifactorial and relatively independent of the acute inflammatory response mediated by LTs. Moreover, inhaled glucocorticoids inhibit numerous airway inflammatory cells and mediators that are pivotal in the AHR pathophysiology, whereas anti-LTs selectively block LT-mediated eosinophilic inflammation [81]. However, while the anti-inflammatory effects of glucocorticoids are undoubtedly broader than those of anti-LTs, effects of anti-LTs may be unexpectedly pleiotropic, in part via their ability to exert indirect 
inhibitory effects on the synthesis or actions of cytokines [1, 40]. CysLT $_{1}$ receptor antagonists are also effective in reducing allergen-induced asthmatic response in children [83].

In Europe, CysLT $_{1}$ receptor antagonists are currently indicated for preventing EIB [3]. Montelukast given at a dose of $10 \mathrm{mg}$ once daily protects against exerciseinduced bronchconstriction over a 12-week period in adults with asthma [84]. Treatment with CysLT $_{1}$ receptor antagonists reduces the time to recovery from the maximal decrease in forced expiratory volume in $1 \mathrm{~s}\left(\mathrm{FEV}_{1}\right)$, the maximal decrease in $\mathrm{FEV}_{1}$, and the area under the $\mathrm{FEV}_{1}$ vs. time curve after exercise [84]. These effects are observed as soon as two hours after a single oral dose of montelukast $(10 \mathrm{mg})$ and are maintained up to $24 \mathrm{~h}[85,86]$. Montelukast is more effective that salmeterol in the chronic treatment of EIB over a period of 8 weeks in adults with mild asthma, as demonstrated by effect size, persistence of effect and higher tolerability during the study period [87]. CysLT $_{1}$ receptor antagonists are effective in EIB in children [88], although generally less effective than inhaled glucocorticoids in children with EIB with persistent asthma [89].

$\mathrm{CysLT}_{1}$ receptor antagonism and 5-LO inhibition protect against the reduction in $\mathrm{FEV}_{1}$ in response to aspirin challenge [3] and improve asthma control in aspirin-sensitive patients over and above the therapeutic response to glucocorticoids, an effect that is independent of the baseline urinary $\mathrm{LTE}_{4}[50,90]$.

Some aspects of the clinical pharmacology of $\mathrm{CysLT}_{1}$ receptor antagonists deserve further discussion: (1) their role as monotherapy in patients with asthma; (2) their additive efficacy with inhaled glucocorticoids and their possible steroid-sparing action; (3) the variability in their therapeutic response across the population; (4) their potential antiremodelling effect in the airways and (5) their safety.

In North America, monotherapy with CysLT $_{1}$ receptor antagonists is a common therapeutic option for patients with mild asthma [91, 92]. However, inhaled glucocorticoids are generally preferred because of their greater efficacy as first-line agents in both adults and children with asthma $[93,94]$. Nonetheless, LTRAs are not an unreasonable choice for a controller in patients who cannot tolerate inhaled glucocorticoids or prefer a non-steroid agent [91, 92].

In patients with asthma not sufficiently controlled with inhaled glucocorticoids alone, add-on therapy with montelukast to a constant dose of inhaled budesonide improves asthma control [95] to a level comparable to that achieved by doubling the dose of budesonide [96]. The advantage of this therapeutic strategy would be the reduced risk of side-effects due to long-term administration of high-dose inhaled glucocorticoids [96]. In patients whose symptoms remain uncontrolled with inhaled fluticasone alone, the addition of montelukast is a therapeutic option [97], although the addition of a long-acting $\beta_{2}$-agonist (LABA) is generally more effective for preventing exacerbations requiring systemic steroids, and for improving lung func- tion, symptoms and the use of rescue $\beta_{2}$-agonists $[98,99]$. In patients with well-controlled asthma based on symptoms and lung function testing, the addition of pranlukast to the combination of inhaled glucocorticoids and LABAs gives better control of airway inflammation compared with therapy with the combination of inhaled glucocorticoid/ LABA alone [100, 101]. In children with mild persistent asthma, montelukast withdrawal can result in enhanced airway inflammation, as reflected by fractional-exhaled nitric oxide $\left(\mathrm{F}_{\mathrm{E}} \mathrm{NO}\right)$ concentrations, and worsening of lung function [102].

Add-on therapy with $\mathrm{CysLT}_{1}$ receptor antagonists enables a reduction in the dose of inhaled glucocorticoids required to control asthma [96, 103]. As the LT pathway is relatively steroid-resistant [104], the combination of LTRAs and inhaled glucocorticoids can increase therapeutic efficacy in subgroups of patients whose asthma is LTdriven. AHR to $\mathrm{LTD}_{4}$ and urinary $\mathrm{LTE}_{4}$ concentrations in adults with mild asthma are not affected by inhaled fluticasone (500 $\mu$ g b.i.d. for 2 weeks) [104]. Treatment with inhaled fluticasone ( $100 \mu \mathrm{g}$ b.i.d. for 4 weeks) reduces $\mathrm{LTE}_{4}$ concentrations in EBC by $18 \%$ in children with intermittent and mild persistent asthma [60]. Taken together, this evidence indicates that inhaled glucocorticoids have limited, if any, effects on the biosynthesis of CysLTs and AHR to CysLTs in patients with asthma [104].

The therapeutic response to $\mathrm{CysLT}_{1}$ receptor antagonists in both adults and children with asthma is variable [96, $105,106]$, but this is also true for inhaled glucocorticoids, and undoubtedly, all classes of medications. Identification of LTRA and/or inhaled glucocorticoid responders might have important clinical implications, as a tailored, individualized approach to asthma management and assessment is preferable for asthma control than a strategy directed to the best outcome in a group of patients [94]. Certain phenotypic features have been linked to a therapeutic response to inhaled fluticasone; these include higher $\mathrm{F}_{\mathrm{E}} \mathrm{NO}$ concentrations, serum IgE, and eosinophil cationic protein concentrations, total blood eosinophil counts, and lower levels of methacholine $\mathrm{FEV}_{1}$ provocative concentration $(\mathrm{PC})_{20}$ and of pulmonary function $[94,105]$. A therapeutic response to montelukast is associated with younger age, shorter disease duration, higher urinary $\mathrm{LTE}_{4}$ concentrations [94, 105], and elevated $\mathrm{LTE}_{4}$ concentrations in EBC [53]. In patients with asthma, the response to inhaled glucocorticoids decreases with the increasing body mass index, whereas the response to montelukast remains intact [107]. Studies on biomolecule profiles in biological fluids and genetic polymorphisms of the 5-LO pathway and CysLT receptors [108] may in the future help to predict the therapeutic response to $\mathrm{CysLT}_{1}$ receptor antagonists. At present, it is not possible to predict in individual patients whether they will respond to LTRAs mandating that a therapeutic trial be performed. 
In a mouse model of asthma, CysLT $_{1}$ receptor antagonists not only prevent allergen-induced airway changes but also reverse established structural changes including subepithelial fibrosis and airway smooth muscle cell layer thickening - effects not achieved by glucocorticoid treatment [109]. These findings suggest a possible role of CysLTs in airway remodelling [42] and may have important implications for the management of patients with asthma as they might indicate new therapeutic effects of CysLT $_{1}$ receptor antagonists. In patients with asthma, inhaled glucocorticoids also reduce basal membrane thickening [110] and subepithelial collagen deposition [111], although these effects seem to have limited impact on the clinical evolution of asthma [112]. In one study, montelukast at a dose of $10 \mathrm{mg}$ once daily for 8 weeks reduced myofibroblast accumulation in the airways observed in biopsies of patients with asthma following low-dose allergen challenge [113]. However, whether CysLT $_{1}$ receptor antagonists prevent airway remodelling and/or reverse established airway structural changes in asthmatic patients require further research.

CysLT $_{1}$ receptor antagonists are generally considered to be safe and well tolerated, with headache and gastric discomfort being the most common side effects [3]. However, an association between treatment with CysLT $_{1}$ receptor antagonists and severe adverse events including Churg-Strauss syndrome [114] and suicidality [115] has been reported. An aetiologic role for CysLT $_{1}$ receptor antagonists in the Churg-Strauss syndrome has been deemed previously unlikely [3]. However, a recent analysis of the FDA adverse event reporting system database has shown that LTRA therapy was a suspect medication in most confirmed cases of Churg-Strauss syndrome reported [114]. In the majority of cases treated with an LTRA, Churg-Strauss syndrome could not be explained by either glucocorticoid withdrawal or pre-existing Churg-Strauss syndrome [114]. Based on a limited number of postmarketing suicide-related adverse experience reports, the FDA issued a warning raising concerns about the suicidality potential of montelukast and other CysLT $_{1}$ receptor antagonists [115]. However, no completed suicides were reported in any studies [115], and in fact, data from clinical studies indicate that adverse experiences possibly related to suicidality were rare and were similar between montelukast and placebo or active-control groups $[115,116]$. There are limited prospective, comparative studies examining the safety of $\mathrm{CysLT}_{1}$ receptor antagonists in pregnancy [117]. Montelukast does not appear to increase the baseline rate of major malformations $[117,118]$. The lower birth weight observed in infants born to women treated with montelukast could be attributed to severity/ control of the maternal asthma $[117,118]$.

Oral administration of CysLT $_{1}$ receptor antagonists provides a single therapeutic approach to both AR and asthma. In asthmatic patients with AR, a combined treat- ment approach that includes montelukast and budesonide is more effective in reducing airflow obstruction compared with doubling the dose of budesonide, indicating that this strategy increases therapeutic efficacy, potentially reducing the number of side-effects [119].

\section{Conclusions}

Most of the knowledge of the pathophysiological role of LTs in asthma is currently limited to CysLT $_{1}$ receptormediated effects, whereas the roles of the CysLT 2 receptor and other emerging receptors are largely unknown. $\mathrm{CysLT}_{1}$ receptor antagonists are generally less effective than inhaled glucocorticoids, but there is a substantial heterogeneity of clinical responsiveness among individual patients. It is not currently possible to predict whether an individual asthmatic will respond to these agents. Among responders, CysLT $_{1}$ receptor antagonists provide a therapeutic alternative to inhaled glucocorticoids in mild persistent asthma. In patients with more severe asthma who respond to $\mathrm{CysLT}_{1}$ receptor antagonists, the addition of these drugs to inhaled glucocorticoids improves asthma control and enables the dose of inhaled gluococorticoids to be reduced without compromising efficacy. LTRAs are also useful in exercise-induced asthma.

The potential effect of $\mathrm{CysLT}_{1}$ receptor antagonists or novel LT synthesis inhibitors in preventing and reversing structural changes that characterize airway remodelling, as well as the role of $\mathrm{LTB}_{4}$ in asthma, requires further study.

\section{Acknowledgement}

This work was supported by the Catholic University of the Sacred Heart, Academic Grant 2009-2010.

\section{References}

1 Peters-Golden M, Henderson WR. Leukotrienes. $N$ Engl J Med 2007; 357:1841-54.

2 Montuschi P, Sala A, Dahlén S-E, Folco G. Pharmacological modulation of the leukotriene pathway in allergic airway disease. Drug Discov Today 2007; 12:404-12.

3 Dahlen SE. Treatment of asthma with antileukotrienes: first line or last resort therapy? Eur J Pharmacol 2006; 533:40-56.

4 Busse W, Kraft M. Cysteinyl leukotrienes in allergic inflammation: strategic target for therapy. Chest 2005; 127:1312-26.

5 Folco G, Murphy RC. Eicosanoid transcellular biosynthesis: from cell-cell interactions to in vivo tissue responses. Pharmacol Rev 2006; 58:1-14.

6 Hallstrand TS, Henderson WR Jr An update on the role of leukotrienes in asthma. Curr Opin Allergy Clin Immunol 2010; 10:60-6.

7 James AJ, Penrose JF, Cazaly AM, Holgate ST, Sampson AP. Human bronchial fibroblasts express the 5-lipoxygenase pathway. Resp Res 2006; 7:102.

8 Lynch KR, O'Neill GP, Liu Q et al. Characterization of the human cysteinyl leukotriene CysLT 1 receptor. Nature 1999; 399:789-93. 
9 Mellor EA, Frank N, Soler D et al. Expression of the type 2 receptor for cysteinyl leukotrienes $\left(\mathrm{CysLT}_{2} \mathrm{R}\right)$ by human mast cells: functional distinction from CysLT $_{1}$ R. Proc Natl Acad Sci USA 2003; 100:11589-93.

10 Maekawa A, Kanaoka Y, Xing W, Austen KF. Functional recognition of a distinct receptor preferential for leukotriene $\mathrm{E}_{4}$ in mice lacking the cysteinyl leukotriene 1 and 2 receptors. Proc Natl Acad Sci USA 2008; 105:16695-700.

11 Maekawa C, Balestrieri B, Austen KF, Kanaoka Y. GPR17 is a negative regulator for the cysteinyl leukotriene 1 receptor response to leukotriene $\mathrm{D}_{4}$. Proc Natl Acad Sci USA 2009; 106:11685-90.

12 Paruchuri S, Tashimo H, Feng C et al. Leukotriene $\mathrm{E}_{4}$-induced pulmonary inflammation is mediated by the $\mathrm{P}_{2} \mathrm{Y}_{12}$ receptor. J Exp Med 2009; 206:2543-55.

13 Lee $\mathrm{TH}$. Leukotriene $\mathrm{E}_{4}$ : perspective on the forgotten mediator. J Allergy Clin Immunol 2009; 124:417-21.

14 Ciana P, Fumagalli M, Trincavelli ML et al. The orphan receptor GPR17 identified as a new dual uracil nucleotides/cysteinylleukotrienes receptor. EMBO J 2006; 25:4615-27.

15 Laitinen LA, Laitinen A, Haahtela T, Vilkka V, Spur BW, Lee TH. Leukotriene $\mathrm{E}_{4}$ and granulocytic infiltration into asthmatic airways. Lancet 1993; 341:989-90.

16 Gauvreau GM, Parameswaran KN, Watson RM, O’Byrne PM. Inhaled leukotriene $\mathrm{E}_{4}$, but not leukotriene $\mathrm{D}_{4}$, increased airway inflammatory cells in subjects with atopic asthma. Am J Respir Crit Care Med 2001; 164:1495-500.

17 O'Hickey SP, Arm JP, Rees PJ, Spur BW, Lee TH. The relative responsiveness to inhaled leukotriene $\mathrm{E}_{4}$, methacholine and histamine in normal and asthmatic subjects. Eur Respir $J$ 1988; 1:913-7.

18 Maekawa A, Xing W, Austen KF, Kanaoka Y. GPR17 regulates immune pulmonary inflammation induced by house dust mites. J Immunol 2010; 185:1846-54.

19 Figueroa DJ, Breyer RM, Defoe SK et al. Expression of the cysteinyl leukotriene 1 receptor in normal human lung and peripheral blood leukocytes. Am J Resp Crit Care Med 2001; 163:226-33.

20 Gauvreau GM, Plitt JR, Baatjes A, MacGlashan DW. Expression of functional cysteinyl leukotriene receptors by human basophils. J Allergy Clin Immunol 2005; 116:80-7.

21 Di Gennaro A, Carnini C, Buccellati C et al. Cysteinyl-leukotrienes receptor activation in brain inflammatory reactions and cerebral edema formation: a role for transcellular biosynthesis of cysteinyl-leukotrienes. FASEB J 2004; 18:842-4.

22 Fujii M, Tanaka $H$, Abe S. Interferon- $\gamma$ up-regulates expression of cysteinyl leukotriene type 2 receptors on eosinophils in asthmatic patients. Chest 2005; 128:3148-55.

23 Figueroa DJ, Borish L, Baramki D, Philip G, Austin CP, Evans JF. Expression of cysteinyl leukotriene synthetic and signalling proteins in inflammatory cells in active seasonal allergic rhinitis. Clin Exp Allergy 2003; 33:1380-8.

24 Wunder F, Tinel H, Kast R et al. Pharmacological characterization of the first potent and selective antagonist at the cysteinyl leukotriene 2 (CysLT $_{2)}$ receptor. Br J Pharmacol 2010; 160:399-409.

25 Naik S, Billington CK, Pascual RM et al. Regulation of cysteinyl leukotriene type 1 receptor internalization and signaling. J Biol Chem 2005; 280:8722-32.

26 Yokomizo T, Izumi T, Chang K, Takuwa Y, Shimizu T. A Gprotein-coupled receptor for leukotriene $\mathrm{B}_{4}$ that mediates chemotaxis. Nature 1997; 387:620-4.
27 Yokomizo T, Kato K, Terawaki K, Izumi T, Shimizu T. A second leukotriene $\mathrm{B}_{4}$ receptor, $\mathrm{BLT}_{2}$. A new therapeutic target in inflammation and immunological disorders. J Exp Med 2000; 192:421-32.

28 Lundeen KA, Sun B, Karlsson L, Fourie AM. Leukotriene $B_{4}$ receptors $\mathrm{BLT}_{1}$ and $\mathrm{BLT}_{2}$ : expression and function in human and murine mast cells. J Immunol 2006; 177:339-447.

29 Ohnishi H, Miyahara N, Gelfand EW. The role of leukotriene $\mathrm{B}_{4}$ in allergic diseases. Allergol Int 2008; 57:291-8.

30 Gelfand EW, Dakhama A. CD8 ${ }^{+}$T lymphocytes and leukotriene $\mathrm{B}_{4}$ : novel interactions in the persistence and progression of asthma. J Allergy Clin Immunol 2006; 117:577-82.

31 Miyahara N, Ohnishi $\mathrm{H}$, Matsuda $\mathrm{H}$ et al. Leukotriene $\mathrm{B}_{4}$ receptor 1 expression on dendritic cells is required for the development of $\mathrm{Th}_{2}$ responses and allergen-induced airway hyperresponsiveness. J Immunol 2008; 181:1170-8.

32 Miyahara N, Takeda K, Miyahara S et al. Leukotriene $\mathrm{B}_{4}$ receptor-1 is essential for allergen-mediated recruitment of $\mathrm{CD}^{+} \mathrm{T}$ cells and airway hyperresponsiveness. J Immunol 2005; 174:4979-84.

33 Ohnishi H, Miyahara N, Dakhama A et al. Corticosteroids enhance $\mathrm{CD}^{+} \mathrm{T}$ cell-mediated airway hyperresponsiveness and allergic inflammation by upregulating leukotriene $\mathrm{B}_{4}$ receptor 1. J Allergy Clin Immunol 2008; 121:864-71.

34 Evans DJ, Barnes PJ, Spaethe SM, van Alstyne EL, Mitchell MI, O'Connor BJ. Effect of a leukotriene $\mathrm{B}_{4}$ receptor antagonist, LY293111, on allergen-induced responses in asthma. Thorax 1996; 51:1178-84.

35 Cho KJ, Seo JM, Shin Y et al. Blockade of airway inflammation and hyperresponsiveness by inhibition of $\mathrm{BLT}_{2}$, a low-affınity leukotriene $\mathrm{B}_{4}$ receptor. Am J Respir Cell Mol Biol 2010; 42:294-303.

36 Narala VR, Adapala RK, Suresh MV, Brock TG, Peters-Golden M, Reddy RC. Leukotriene $\mathrm{B}_{4}$ is a physiologically relevant endogenous peroxisome proliferator-activated receptor- $\alpha$ agonist. J Biol Chem 2010; 285:22067-74.

37 Hallstrand TS, Moody MW, Wurfel MM, Schwartz LB, Henderson WR Jr, Aitken ML. Inflammatory basis of exercise-induced bronchoconstriction. Am J Respir Crit Care Med 2005; 172:679-86.

38 Kikawa Y, Miyanomae T, Inoue $\mathrm{Y}$ et al. Urinary leukotriene $\mathrm{E}_{4}$ after exercise challenge in children with asthma. J Allergy Clin Immunol 1992; 89:1111-9.

39 Diamant Z, Hiltermann JT, van Rensen EL et al. The effect of inhaled leukotriene $\mathrm{D}_{4}$ and methacholine on sputum cell differentials in asthma. Am J Resp Crit Care Med 1997; 155:1247-53.

40 Peters-Golden M. Expanding roles for leukotrienes in airway inflammation. Curr Allergy Asthma Rep 2008; 8:367-73.

41 Kim DC, Hsu FI, Barrett NA et al. Cysteinyl leukotrienes regulate $\mathrm{Th}_{2}$ cell-dependent pulmonary inflammation. J Immunol 2006; 176:4440-8.

42 Mehrotra AK, Henderson WR Jr. The role of leukotrienes in airway remodeling. Curr Mol Med 2009; 9:383-91.

43 Wenzel SE, Szefler SJ, Leung DY, Sloan SI, Rex MD, Martin RJ. Bronchoscopic evaluation of severe asthma. Persistent inflammation associated with high dose glucocorticoids. Am J Resp Crit Care Med 1997; 156:737-43.

44 Rao NL, Riley JP, Banie $\mathrm{H}$ et al. Leukotriene $\mathrm{A}_{4}$ hydrolase inhibition attenuates allergic airway inflammation and hyperresponsiveness. Am J Respir Crit Care Med 2010; 181:899-907. 
45 Sampson AP, Castling DP, Green CP, Price JF. Persistent increase in plasma and urinary leukotrienes after acute asthma. Arch Dis Child 1995; 73:221-5.

46 Montuschi P, Barnes PJ. Exhaled leukotrienes and prostaglandins in asthma. J Allergy Clin Immunol 2002; 109:615-20.

47 Montuschi P, Martello S, Felli M, Mondino C, Chiarotti M. Liquid chromatography/mass spectrometry analysis of exhaled leukotriene $\mathrm{B}_{4}$ in asthmatic children. Respir Res 2005; 6:119.

48 Fourie AM. Modulation of inflammatory disease by inhibitors of leukotriene $\mathrm{A}_{4}$ hydrolase. Curr Opin Invest Drugs 2009; 10: 1173-82.

49 Riccioni G, Vecchia RD, D’Orazio N, Sensi S, Guagnano MT. Comparison of montelukast and budesonide on bronchial reactivity in subjects with mild-moderate persistent asthma. Pulm Pharmacol Ther 2003; 16:111-4.

50 Dahlen B, Nizankowska E, Szczeklik A et al. Benefits from adding the 5-lipoxygenase inhibitor zileuton to conventional therapy in aspirin-intolerant asthmatics. Am J Resp Crit Care Med 1998; 157:1187-94.

51 Fischer AR, McFadden CA, Frantz R et al. Effect of chronic 5-lipoxygenase inhibition on airway hyperresponsiveness in asthmatic subjects. Am J Respir Crit Care Med 1995; 152:1203-7.

52 Berges-Gimeno MP, Simon RA, Stevenson MD. The effect of leukotriene-modifier drugs on aspirin-induced asthma and rhinitis reactions. Clin Exp Allergy 2002; 32:1491-6.

53 Montuschi P, Mondino C, Koch P, Barnes PJ, Ciabattoni G. Effects of a leukotriene receptor antagonist on exhaled leukotriene $\mathrm{E}_{4}$ and prostanoids in asthmatic children. J Allergy Clin Immunol 2006; 118:347-53.

54 Montuschi P, Martello S, Felli M, Mondino C, Chiarotti M. Ion trap liquid chromatography/tandem mass spectrometry analysis of leukotriene $\mathrm{B}_{4}$ in exhaled breath condensate. Rapid Commun Mass Spectrom 2004; 18:2723-9.

55 Kostikas K, Gaga M, Papatheodorou G, Karamanis T, Orphanidou D, Loukides $\mathrm{S}$. Leukotriene $\mathrm{B}_{4}$ in exhaled breath condensate and sputum supernatant in patients with COPD and asthma. Chest 2005; 127:1553-9.

56 Montuschi P., ed. New perspectives in monitoring lung inflammation: analysis of exhaled breath condensate 2005. Boca Raton, FL: CRC Press.

57 Antczak A, Montuschi P, Kharitonov S, Gorski P, Barnes PJ. Increased exhaled cysteinyl leukotrienes and 8-isoprostane in aspirin-induced asthma. Am J Respir Crit Care Med 2002; 166: 301-6.

58 Zanconato S, Carraro S, Corradi M et al. Leukotrienes and 8-isoprostane in exhaled breath condensate of children with stable and unstable asthma. J Allergy Clin Immunol 2004; 113: 257-63.

59 Shibata A, Katsunuma T, Tomikawa M et al. Increased leukotriene $\mathrm{E}_{4}$ in the exhaled breath condensate of children with mild asthma. Chest 2006; 130:1718-22.

60 Mondino C, Ciabattoni G, Koch P et al. Effects of inhaled corticosteroids on exhaled leukotrienes and prostanoids in asthmatic children. J Allergy Clin Immunol 2004; 114:761-7.

61 Csoma Z, Kharitonov SA, Balint B, Bush A, Wilson NM, Barnes PJ. Increased leukotrienes in exhaled breath condensate in childhood asthma. Am J Respir Crit Care Med 2002; 166:1345-9.

62 Aggarwal S, Moodley YP, Thompson PJ, Misso NL. Prostaglan$\operatorname{din} E_{2}$ and cysteinyl leukotriene concentrations in sputum: association with asthma severity and eosinophilic inflammation. Clin Exp Allergy 2010; 40:85-93.

63 Pavord ID, Ward R, Woltmann G, Wardlaw AJ, Sheller JR, Dworski R. Induced sputum eicosanoid concentrations in asthma. Am J Resp Crit Care Med 1999; 160:1905-9.

64 Wenzel SE, Trudeau JB, Kaminsky DA, Cohn J, Martin RJ, Westcott JY. Effect of 5-lipoxygenase inhibition on bronchoconstriction and airway inflammation in nocturnal asthma. Am J Respir Crit Care Med 1995; 152:897-905.

65 Kumlin M. Measurement of leukotrienes in humans. Am J Resp Crit Care Med 2000; 161:S102-6.

66 Higashi N, Taniguchi M, Mita $\mathrm{H}$ et al. Clinical features of asthmatic patients with increased urinary leukotriene $\mathrm{E}_{4}$ excretion (hyperleukotrienuria): involvement of chronic hyperplastic rhinosinusitis with nasal polyposis. J Allergy Clin Immunol 2004; 113:277-83.

67 Green SA, Malice MP, Tanaka W, Tozzi CA, Reiss TF. Increase in urinary leukotriene $\mathrm{LTE}_{4}$ levels in acute asthma: correlation with airflow limitation. Thorax 2004; 59:100-4.

68 Montuschi P. Analysis of exhaled breath condensate in respiratory medicine: methodological aspects and potential clinical applications. Ther Adv Respir Dis 2007; 1:5-23.

69 Horvath I, Hunt J, Barnes PJ et al. ATS/ERS Task Force on Exhaled Breath Condensate. Exhaled breath condensate: methodological recommendations and unresolved questions. Eur Resp J 2005; 26:523-48.

70 Christie PE, Tagari P, Ford-Hutchinson AW et al. Urinary leukotriene $\mathrm{E}_{4}$ after lysine-aspirin inhalation in asthmatic subjects. Am Rev Respir Dis 1992; 146:1531-4.

71 Anon. The ENFUMOSA cross-sectional European multicentre study of the clinical phenotype of chronic severe asthma. European Network for Understanding Mechanisms of Severe Asthma. Eur Resp J 2003; 22:470-7.

72 Friedman BS, Bel EH, Buntinx A et al. Oral leukotriene inhibitor (MK-886) blocks allergen-induced airway responses. Am Rev Resp Dis 1993; 147:839-44.

73 Diamant Z, Timmers MC, van der Veen H et al. The effect of MK0591, a novel 5-lipoxygenase activating protein inhibitor, on leukotriene biosynthesis and allergen-induced airway responses in asthmatic subjects in vivo. J Allergy Clin Immunol 1995; 95:42-51.

74 Hamilton AL, Watson RM, Wyile G, O'Byrne PM. Attenuation of early and late phase allergen-induced bronchoconstriction in asthmatic subjects by a 5-lipoxygenase activating protein antagonist, BAYx 1005. Thorax 1997; 52:348-54.

75 Sampson AP. FLAP inhibitors for the treatment of inflammatory diseases. Curr Opin Investig Drugs 2009; 10:1163-72.

76 Lorrain DS, Bain G, Correa LD et al. Pharmacological characterization of 3-[3-tert-butylsulfanyl-1-[4-(6-methoxy-pyridin3-yl)-benzyl]-5-(pyridin-2-ylmethoxy)-1H-indol-2-yl]-2, 2dimethyl-propionic acid (AM103), a novel selective 5-lipoxygenase-activating protein inhibitor that reduces acute and chronic inflammation. J Pharmacol Exp Ther 2009; 331:1042-50.

77 Bain G, King CD, Rewolinski M et al. Pharmacodynamics and pharmacokinetics of AM103, a novel inhibitor of 5-lipoxygenase-activating protein (FLAP). Clin Pharmacol Ther 2010; 87:437-44.

78 Busse W, Raphael GD, Galant S et al. Fluticasone Proprionate Clinical Research Study Group. Low-dose fluticasone 
propionate compared with montelukast for first-line treatment of persistent asthma: a randomized clinical trial. J Allergy Clin Immunol 2001; 107:461-8.

79 Camargo CA Jr, Smithline HA, Malice MP, Green SA, Reiss TF. A randomized controlled trial of intravenous montelukast in acute asthma. Am J Resp Crit Care Med 2003; 167:528-33.

80 Camargo CA Jr, Gurner DM, Smithline HA et al. A randomized placebo-controlled study of intravenous montelukast for the treatment of acute asthma. J Allergy Clin Immunol 2010; 125:374-80.

81 Leigh R, Vethanayagam D, Yoshida M et al. Effects of montelukast and budesonide on airway responses and airway inflammation in asthma. Am J Resp Crit Care Med 2002; 166:1212-7.

82 Roquet A, Dahlén B, Kumlin M et al. Combined antagonism of leukotrienes and histamine produces predominant inhibition of allergen-induced early and late phase airway obstruction in asthmatics. Am J Resp Crit Care Med 1997; 155:1856-63.

83 Phipatanakul W, Nowak-Wegrzyn A, Eggleston PA et al. The efficacy of montelukast in the treatment of cat allergen-induced asthma in children. J Allergy Clin Immunol 2002; 109:794-9.

84 Leff JA, Busse WW, Pearlman D et al. Montelukast, a leukotriene-receptor antagonist, for the treatment of mild asthma and exercise-induced bronchoconstriction. N Engl J Med 1998; 339:147-52.

85 Pearlman DS, van Adelsberg J, Philip G et al. Onset and duration of protection against exercise-induced bronchoconstriction by a single oral dose of montelukast. Ann Allergy Asthma Immunol 2006; 97:98-104.

86 Philip G, Pearlman DS, Villarán C et al. Single-dose montelukast or salmeterol as protection against exercise-induced bronchoconstriction. Chest 2007; 132:875-83.

87 Villaran C, 0’Neill SJ, Helbling A et al. Montelukast versus salmeterol in patients with asthma and exercise-induced bronchoconstriction. Montelukast/salmeterol exercise study group. J Allergy Clin Immunol 1999; 104:547-53.

88 Melo RE, Solé D, Naspitz CK. Exercise-induced bronchoconstriction in children: montelukast attenuates the immediatephase and late-phase responses. J Allergy Clin Immunol 2003; 111:301-7.

89 Grzelewski T, Stelmach I. Exercise-induced bronchoconstriction in asthmatic children: a comparative systematic review of the available treatment options. Drugs 2009; 69:1533-53.

90 Dahlen SE, Malmström K, Nizankowska E et al. Improvement of aspirin-intolerant asthma by montelukast, a leukotriene antagonist: a randomized, double-blind, placebo-controlled trial. Am J Resp Crit Care Med 2002; 165:9-14.

91 FitzGerald JM, Shahidi N. Achieving asthma control in patients with moderate disease. J Allergy Clin Immunol 2010; 125:307-11.

92 Lougheed MD, Lemière C, Dell SD et al. Canadian Thoracic Society Asthma Management Continuum - 2010 Consensus Summary for children six years of age and over, and adults. Can Respir J 2010; 17:15-24.

93 National Asthma Education and Prevention Program. Expert Panel Report (EPR-3): guidelines for the Diagnosis and Management of Asthma-Summary Report 2007. J Allergy Clin Immunol 2007; 120:S94-138.

94 Szefler SJ, Phillips BR, Martinez FD et al. Characterization of within-subject responses to fluticasone and montelukast in childhood asthma. J Allergy Clin Immunol 2005; 115:233-42.
95 Vaquerizo MJ, Casan P, Castillo J et al. CASIOPEA (Capacidad de Singulair Oral en la Prevencion de Exacerbaciones Asmaticas) Study Group. Effect of montelukast added to inhaled budesonide on control of mild to moderate asthma. Thorax 2003; 58:204-10.

96 Price DB, Hernandez D, Magyar P et al. Clinical Outcomes with Montelukast as a Partner Agent to Corticosteroid Therapy (COMPACT) International Study Group. Randomised controlled trial of montelukast plus inhaled budesonide versus double dose inhaled budesonide in adult patients with asthma. Thorax 2003; 58:211-6.

97 Bjermer L, Bisgaard H, Bousquet $\mathrm{J}$ et al. Montelukast and fluticasone compared with salmeterol and fluticasone in protecting against asthma exacerbation in adults: one year, double blind, randomised, comparative trial. BMJ 2003; 327:891.

98 Ducharme FM, Lasserson TJ, Cates CJ. Long-acting $\beta_{2}$-agonists versus anti-leukotrienes as add-on therapy to inhaled corticosteroids for chronic asthma. Cochrane Database Syst Rev 2006; (4), CD003137.

99 Lemanske RF Jr, Mauger DT, Sorkness CA et al. Step-up therapy for children with uncontrolled asthma receiving inhaled corticosteroids. N Engl J Med 2010; 362:975-85.

100 Ohbayashi H, Shibata N, Hirose T, Adachi M. Additional effects of pranlukast in salmeterol/fluticasone combination therapy for the asthmatic distal airway in a randomized crossover study. Pulm Pharmacol Ther 2009; 22:574-9.

101 Tomari S, Matsuse H, Hirose $\mathrm{H}$ et al. Observational study of the additive effects of pranlukast on inflammatory markers of clinically stable asthma with inhaled corticosteroids and longacting beta 2 agonists. Respiration 2008; 76:398-402.

102 Montuschi P, Mondino C, Koch P, Ciabattoni G, Barnes PJ, Baviera G. Effects of montelukast treatment and withdrawal on fractional exhaled nitric oxide and lung function in children with asthma. Chest 2007; 132:1876-81.

103 Lofdahl CG, Reiss TF, Leff JA et al. Randomised, placebo controlled trial of effect of a leukotriene receptor antagonist, montelukast, on tapering inhaled corticosteroids in asthmatic patients. BMJ 1999; 319:87-90.

104 Gyllfors P, Dahlén SE, Kumlin M, Larsson K, Dahlén B. Bronchial responsiveness to leukotriene $\mathrm{D}_{4}$ is resistant to inhaled fluticasone propionate. J Allergy Clin Immunol 2006; 118:78-83.

105 Szefler SJ, Martin RJ. Lessons learned from variation in response to therapy in clinical trials. J Allergy Clin Immunol 2010; 125:285-92.

106 Malmstrom K, Rodriguez-Gomez G, Guerra J et al. Oral montelukast, inhaled beclomethasone, and placebo for chronic asthma. Ann Intern Med 1999; 130:487-95.

107 Peters-Golden M, Swern A, Bird SS, Hustad CM, Grant E, Edelman JM. Influence of body mass index on the response to asthma controller agents. Eur Respir J 2006; 27:495-503.

108 Lima JJ, Zhang S, Grant A et al. Influence of leukotriene pathway polymorphisms on response to montelukast in asthma. Am J Respir Crit Care Med 2006; 173:379-85.

109 Henderson WR Jr, Chiang GK, Tien YT, Chi EY. Reversal of allergen-induced airway remodeling by $\mathrm{CysLT}_{1}$ receptor blockade. Am J Resp Crit Care Med 2006; 173:718-28.

110 Ward C, Pais M, Bish R et al. Airway inflammation, basement membrane thickening and bronchial hyperresponsiveness in asthma. Thorax 2002; 57:309-16. 
111 Hoshino M, Takahashi M, Takai Y, Sim J. Inhaled corticosteroids decrease subepithelial collagen deposition by modulation of the balance between matrix metalloproteinase- 9 and tissue inhibitor of metalloproteinase-1 expression in asthma. J Allergy Clin Immunol 1999; 104:356-63.

112 Bisgaard H, Hermansen MN, Loland L, Halkjaer LB, Buchvald F. Intermittent inhaled corticosteroids in infants with episodic wheezing. N Engl J Med 2006; 354:1998-2005.

113 Kelly MM, Chakir J, Vethanayagam D et al. Montelukast treatment attenuates the increase in myofibroblasts following low-dose allergen challenge. Chest 2006; 130:741-53.

114 Bibby S, Healy B, Steele R, Kumareswaran K, Nelson H, Beasley R. Association between leukotriene receptor antagonist therapy and Churg-Strauss syndrome: an analysis of the FDA AERS database. Thorax 2010; 65:132-8.
115 Philip G, Hustad C, Noonan G et al. Reports of suicidality in clinical trials of montelukast. J Allergy Clin Immunol 2009; 124:691-6.

116 Holbrook JT, Harik-Khan R. Montelukast and emotional well-being as a marker for depression: results from 3 randomized, doublemasked clinical trials. J Allergy Clin Immunol 2008; 122:828-9.

117 Sarkar M, Koren G, Kalra S et al. Montelukast use during pregnancy: a multicentre, prospective, comparative study of infant outcomes. Eur J Clin Pharmacol 2009; 65:1259-64.

118 Bakhireva LN, Jones KL, Schatz M et al. Safety of leukotriene receptor antagonists in pregnancy. J Allergy Clin Immunol 2007; 119:618-25.

119 Price DB, Swern A, Tozzi CA, Philip G, Polos P. Effect of montelukast on lung function in asthma patients with allergic rhinitis: analysis from the COMPACT trial. Allergy 2006; 61:737-42. 